\title{
Interactive E-Note and Problem-Solving Strategies Effects on Junior Secondary School Students' Achievements in Mathematics, Kaduna-Nigeria
}

\author{
S. Abiade Olumuyiwa ${ }^{1 *}$ (D), M. Kolawole Akinsola ${ }^{2}$ (D)
}

${ }^{1}$ Federal College of Forestry Mechanization, P.M.B 2273, Afaka Kaduna, NIGERIA

${ }^{2}$ Department of Science and Technology Education, University of Ibadan, Oyo State, NIGERIA

*Corresponding Author: asamson2008@yahoo.com

Citation: Olumuyiwa, S. A., \& Akinsola, M. K. (2021). Interactive E-Note and Problem-Solving Strategies Effects on Junior Secondary School Students' Achievements in Mathematics, Kaduna-Nigeria. Contemporary Mathematics and Science Education, 2(1), ep21008. https://doi.org/10.30935/conmaths/10787

\begin{abstract}
Mathematics aids the development of science and technology, but many secondary school students perform poorly in it in public examinations in Kaduna-Nigeria due to ineffective instructional strategies adopted by teachers. Hence the need to complement mathematics teaching with tools that could engage learners actively. Interactive e-note Mathematics Instructional Strategy (IMIS) and Problem-Solving Strategy (PSS) capability of enhancing students' achievement in mathematics in junior secondary schools were determined by this study with moderating effects of gender and school type.

The pretest-posttest control group quasi-experimental design using 3x2x2 factorial matrix was adopted. Three private and public schools were purposively selected and randomly assigned to IMIS (134), PSS (134) and control (132) groups from two randomized Local Government Areas within Kaduna. Instrumentation are Mathematics Achievement Test $(r=0.87)$ and instructional guides. Data analysis was by Analysis of covariance and Bonferroni post-hoc test at 0.05 level of significance.

Treatment, School type had significant main effect on students achievement in mathematics $\left(\mathrm{F}_{(2,385)}=7.01\right.$; partial $\left.\eta^{2}=0.04\right),\left(F_{(1,385)}=27.63 ;\right.$ partial $\left.\eta^{2}=0.07\right)$ in private school respectively. Post achievement mean score are IMIS (21.48), control (20.42) and PSS (20.30). Treatment and school type had significant interaction effect on mathematics achievement $\left(\mathrm{F}_{(2,385)}=12.23\right.$; partial $\left.\mathrm{n}^{2}=0.06\right)$ from private school in control group.

Mathematics aids the development of science and technology, but many secondary school students perform poorly in it in public examinations in Kaduna-Nigeria due to ineffective instructional strategies adopted by teachers. Hence the need to complement mathematics teaching with tools that could engage learners actively. Interactive e-note Mathematics Instructional Strategy (IMIS) and Problem-Solving Strategy (PSS) capability of enhancing students' achievement in mathematics in junior secondary schools were determined by this study with moderating effects of gender and school type.

The pretest-posttest control group quasi-experimental design using 3x2x2 factorial matrix was adopted. Three private and public schools were purposively selected and randomly assigned to IMIS (134), PSS (134) and control (132) groups from two randomized Local Government Areas within Kaduna. Instrumentation are Mathematics Achievement Test $(r=0.87)$ and instructional guides. Data analysis was by Analysis of covariance and Bonferroni post-hoc test at 0.05 level of significance.

Treatment, School type had significant main effect on students achievement in mathematics $\left(\mathrm{F}_{(2,385)}=7.01\right.$; partial $\left.\eta^{2}=0.04\right),\left(F_{(1,385)}=27.63 ;\right.$ partial $\left.n^{2}=0.07\right)$ in private school respectively. Post achievement mean score are IMIS (21.48), control (20.42) and PSS (20.30). Treatment and school type had significant interaction effect on mathematics achievement $\left(\mathrm{F}_{(2,385)}=12.23\right.$; partial $\left.\eta^{2}=0.06\right)$ from private school in control group.

Keywords: interactive e-note strategy, problem-solving strategy, students' achievement in mathematics, private school, public school

Received: 31 Aug. $2020 \bullet$ Accepted: 24 Nov. 2020
\end{abstract}

\section{INTRODUCTION}

Mathematics is pivotal to the success of any venture in life, be it engineering, medicine, teaching and even in the business world, and therefore, Mathematics can be referred to as a fundamental science necessary for the understanding of other fields. It occupies a central position in the school curriculum as one of the core subjects at the junior and senior secondary school levels of education in Nigeria.

( 2021 by the authors; licensee CONMATHS by Bastas, UK. This article is an open access article distributed under the terms and conditions of the Creative Commons Attribution License (http://creativecommons.org/licenses/by/4.0/). 
Mathematics has an enormous impact on science and the society at large; the influence may be silent and appear hidden, but has shaped our world in many ways (Gauss, 2010). Mathematical ideas have made possible the revolution of electronics, which has transformed the way we think and live today (Gauss, 2010). A lot of changes have come up in the field of sciences and technology as a result of mathematics advancement (Amao and Disu, 2012; Delving, 2009; Jain, 2010; Jegede, 2011; Olusi \& Anuolu, 2010). If Nigeria economy will grow and develop according to nation expectation there is a need for mathematical knowledge and idea that can enable science and technology to come into limelight to bring desirable economy changes in the nation (Kolawole, 2007). For any nation to experience sustainable nation building, there are roles to be played by mathematics education. As far back as when formal education started in Nigeria, Mathematics education has experienced different changes or revolution from different time to the other such as from Arithmetic, Algebra to Geometry and so forth.

Recognition of importance of mathematics to development of nation in the area of science and technology in the society has led to the various trends that mathematics has been going through till recent time. Mathematics has been recognized as basic analytical tools for different theories postulation in different fields, especially science related fields (Amao, 2015). Mathematics is very useful in scientific research because of its value in describing experiments and observations. Mathematics is very useful in almost science-related field to interpret model, concepts and theories. Nobody can really advance in sciences and other related fields without Mathematics (Eze, 2007; Jain, 2010).

Mathematics is an indispensable tool for proper understanding of society and the world around. Mathematics laid foundation for science of structure, along with order, and relation because all these moves around mathematical concepts such as mode of counting, measurement and as well as description of objects in different shapes. Mathematics involves quantitative analysis and calculation as well as logical reasoning (Grouba, 2008). The importance of Mathematics is noted by individual in the aspects of making valuable decision and also in various business and finance decisions. It provides tools for better knowledge of economics, science and technology of any nation. Mathematical ideas can be very useful in taking rational decision in public matter as well as involvement in nation economy through knowledge of its status (The Strategies, 2007). The basic tools that can help the students to critically analyse, explain and bring changes to the world in which they live can be acquired through the knowledge of mathematics (Beans, 2008). Foundational knowledge of Mathematics is very essential in securing admission to desirable career and getting desirable job. It is very important in the modern time advancement in technology. Students can limit their career choices if they fail to learn mathematics earlier enough at their high school (Meece, Wigfield, \& Eccles, 2010). Mathematics helps individuals understanding the world in which they live (Rene Descartes, 1596-1650; Nokoe, 2008). Descartes affirmed that science depends on Mathematics. Nokoe (2008) did not accept the assumption of George Berkeley (1685-1753) and David Hume (17111776) that Mathematics is merely ordinary ideas without any meaningful things to be deducted from it. Nokoe (2008) reacted that mathematics gives direction to sciences. The reason for misrepresentation of mathematics is its formulas that requires individual to cram for accurate computation and despite this misconception of Mathematics, it is still the cornerstones of any advancement in science and technology of any nation (Nokoe, 2008). Mathematics has been seen as mode of communication that is rightly useful to different scientific researchers (Uzo, 2002). Mathematics is considered to be body of knowledge that allows different field of studies to arrive at solution to any identified problem through rightful perception and formulation of certain ways to solve a particular problem specified (Odili, 2012). Alechenu (2012) affirmed that mathematics is the root at which other science related subject could be appropriately understood and without knowledge of mathematics those science-related subjected can be difficult to learn. Alechenu (2012) stated that mathematics is behind any advancement in science and technology of any nation, therefore, government should embrace the teaching and learning of mathematics and should not underestimate the role of mathematics education in this modern time of rapid development of technology.

Although mathematics is very important to scientific and technological development of any nation, but some students still fear Mathematics (Amao, 2015). Students' achievement in Mathematics has not been encouraging and it has become a perpetual educational problem in Nigeria. The core nature of Mathematics in schools has made the poor students' achievement in Mathematics a major concern to researchers in the field of Mathematics education (Abakpa \& AgboEgwu, 2008; Sanni \& Ochepa, 2002; Uloko \& Imoko, 2007). In 2006 the failure rate in Mathematics was not encouraging because Nigerian students overall performance in Mathematics was so low to the extent that Nigeria as a nation held $10^{\text {th }}$ position out of eleven nations involved in School Certificate Examinations (Abakpa \& Agbo-Egwu, 2008). Many students in tertiary institutions in Nigeria today are not studying the courses of their choice because of not making the required grades in ordinary level Mathematics in the same School Certificate Examination. Most students regard making Mathematics compulsory at primary and secondary school levels as a punishment (Obodo, 2004). Students' performance in classroom as well as external examinations in Mathematics has not been encouraging because students persistently display poor knowledge of mathematical skills and concepts (Abakpa \& Agbo-Egwu, 2008). WAEC (2014) also affirms the students' poor performance in Mathematics through its statistical reports over a period of time. Table 1. further attest to student's poor performance in Mathematics from 2005-2017 in Nigeria. This trend was also noticed in Basic Education Certificate Examination, which is also known as BECE, Mathematics result from 2011-2016 as analysed in Table 2.

Table 1 gives the reports on students' performance at the senior secondary certificate examination from 2005 to 2017 in Mathematics. The table reveals that students performance with grades A1-C6 recorded the highest percentage (59.22\%) in 2017 followed by $(52.3 \%)$ in 2008. There was noticeable improvement in students' performance from the year 2005 to 2008 . Year 2009 to 2011 recorded decline in the performance of students' with grades A1 -C6 from 47.0\% to $40.4 \%$. There had been a consistent poor performance since 2012 until 2017 where we have marked improvement. The West African Examination Council (WAEC) Chief Examiners report (2012) suggested that, for a student to come out with good performance in Mathematics, they should study the syllabus in order to know the scope of coverage, be encouraged to study effectively and be exposed to mathematical facts, concepts and principles as well as how to apply them accurately in answering questions and also be well exposed to past WASSCE questions.

From Table 2 the highest percentage scores of students in basic education certificate examination (BECE) Mathematics within the six 
Table 1. Analysis of W ASSCE Mathematics Results of May/June 2005 -2017 in Nigeria

\begin{tabular}{|c|c|c|c|c|c|c|c|}
\hline \multicolumn{8}{|c|}{ NUMBER AND PERCENT AGE OBTAINING GRADE } \\
\hline YEAR & $\begin{array}{c}\text { Total Enrolled for } \\
\text { Exam }\end{array}$ & $\begin{array}{l}\text { A1-C6 Higher } \\
\text { Passes }\end{array}$ & $\begin{array}{l}\text { \% Higher } \\
\text { Passes }\end{array}$ & D7-E8 Poor Passes & \% Poor Passes & $\begin{array}{l}\text { F9 Outright } \\
\text { Failure }\end{array}$ & $\begin{array}{l}\text { \% Outright } \\
\text { Failure }\end{array}$ \\
\hline 2005 & $1,054,853$ & 402,982 & 38.20 & 276,000 & 25.36 & 363,055 & 34.41 \\
\hline 2006 & $1,181,515$ & 482,123 & 40.81 & 366,801 & 31.04 & 332591 & 28.15 \\
\hline 2007 & $1,249,028$ & 583,921 & 46.75 & 333,740 & 26.72 & 302,764 & 24.24 \\
\hline 2008 & $1,292,890$ & 726,398 & 52.27 & 302,266 & 23.83 & 218,618 & 17.23 \\
\hline 2009 & $1,373,009$ & 634,382 & 47.04 & 344,635 & 25.56 & 315,738 & 23.41 \\
\hline 2010 & $1,306,535$ & 548,065 & 41.95 & 363,920 & 26.85 & 355,382 & 27.20 \\
\hline 2011 & $1,508,965$ & 608,866 & 40.40 & 474,664 & 31.50 & 421,412 & 27.90 \\
\hline 2012 & $1,550,224$ & 723,024 & 46.64 & 445,224 & 28.72 & 380,425 & 24.54 \\
\hline 2013 & $1,399,178$ & 618,996 & 44.24 & 371,202 & 26.53 & 406,181 & 29.03 \\
\hline 2014 & $1,547,178$ & 621,950 & 40.20 & 427,342 & 30.53 & 451,301 & 29.17 \\
\hline 2015 & $1,593,442$ & 544,638 & 34.18 & 598,401 & 37.55 & 450,403 & 28.27 \\
\hline 2016 & $1,544,234$ & 597,310 & 38.68 & 446,302 & 28.90 & 500,622 & 32.42 \\
\hline
\end{tabular}

Source: The West African Examinations Council 2005 - 2017 WASSCE Mathematics Result

Table 2. Analysis of BECE Mathematics Result, 2011 - 2016

\begin{tabular}{|c|c|c|c|c|c|c|c|c|}
\hline YEAR & TOTAL CANDIDATES & $\mathbf{A}(\%)$ & B (\%) & $\mathrm{C}(\%)$ & D (\%) & E (\%) & F (\%) & NG (\%) \\
\hline 2011 & 56,025 & $9,244(16.5)$ & $19,217(34.3)$ & $16,135(28.8)$ & $8,908(15.9)$ & $1,961(3.5)$ & $504(0.9)$ & $56(0.1)$ \\
\hline 2012 & 58,069 & $9,001(15.5)$ & $19,260(33.2)$ & $17,576(30.3)$ & $9,794(16.9)$ & $1,916(3.3)$ & $465(0.8)$ & $58(0.1)$ \\
\hline 2013 & 59,088 & $6,795(11.5)$ & $20,445(34.6)$ & $19,972(33.8)$ & $9,690(16.4)$ & $1,773(.3 .0)$ & $355(0.6)$ & $59(0.1)$ \\
\hline 2014 & 59,620 & $5,545(9.3)$ & $19,078(31.8)$ & $20,688(34.7)$ & $11,864(19.9)$ & $1,968(3.3)$ & $358(0.6)$ & $59(0.1)$ \\
\hline 2015 & 58,874 & $6,535(11.1)$ & $18,722(31.8)$ & $19,016(32.3)$ & $11,775(20.4)$ & $2,218(3.8)$ & $353(0.6)$ & $58(0.1)$ \\
\hline 2016 & 59,412 & 9,324 (15.7) & $19,126(32.2)$ & $20,327(34.2)$ & $8,620(14.5)$ & $1,477(2.5)$ & $480(0.8)$ & $58(0.1)$ \\
\hline
\end{tabular}

Source: National Examinations Council (NECO), 2011 - 2016

year period was $34.3 \%$ in $2011,33.2 \%$ in $2012,34.6 \%$ in $2013,34.7 \%$ in 2014, 32.3\% in 2015 and $34.2 \%$ in 2016. The first three years, 2011, 2012, and 2013 resulted in students obtaining a B grade while the last three years show that many of the students obtained a $\mathrm{C}$ grade. A careful study of this result shows that more than $50 \%$ of the students obtained between grades $\mathrm{A}$ to $\mathrm{C}$ but there is still the need for improvement on the teaching strategy being employed at this level of education in Nigeria to further enhanced students better performance in Mathematics.

One major factor in the achievement of students is the teacher. In fact, teachers are central to the performance of students. The National Policy on Education (NPE) asserted that no educational system can rise above the quality of its teachers (FRN, 2004). The quality in this context refers to teacher attitudes, teaching experience of the teacher and their versatility on methodology. Teacher's attitude is a great determinant of students' disposition to learning of Mathematics. Yara (2008) affirmed that students' academic performance and their disposition to learning of mathematics are determined by their teacher attitude towards Mathematics. Ofoegbu (2004) identified poor disposition to work and inappropriate teaching habits of teachers as part of factors affecting students' performance in mathematics.

There are several teaching strategies recommended by different researchers which are not limited to problem-solving strategy (Popoola, 2002), cooperative teaching strategy (Akinsola \& Ifamuyiwa, 2008), mastery learning strategy (Abakpa \& Iji, 2011), personalization approach (Akinsola \& Awofala, 2009) and concept mapping (Awofala, 2011) among many others. Those recommended strategies are to improve students' academic performance and attitudes to Mathematics as well as general assessment in Mathematics. This present study focused on how to improve the teaching of Mathematics in junior secondary schools using interactive e-note and problem solving strategies.

The conventional strategy barely focused on how computer can be used by the students to bring about positive improvement in learning and the society they live through the knowledge of mathematics (Mukhopadhuyay \& Greer, 2007). Application of computer has been basically on how it can improve teaching and less emphasis has been given to the learning or how students learn. Many teachers do not involve students in what they learn because they think that they have nothing to contribute, therefore, there is need for suitable pedagogical approaches to effectively deliver mathematics lesson to the learners. This bring about therefore the reason to research into other new and innovative teaching strategy such as interactive e-note Mathematics Instruction to bring about improved performance in the learning of Mathematics. If the teacher teaches Mathematics with appropriate innovative teaching strategies, students on their own will identify varieties of ways in which mathematics is very useful to them personally and within the classroom environment (Gonzales, Andrade, Civil, \& Moll, 2001; Gutstein \& Peterson, 2005). The students will be able to understand the implications and benefits of world decision making and even in their immediate society through the inclusion of mathematical ideas in the area of economy and political decision (Orey \& Rosa, 2006; Mukhopadhuyay \& Greer, 2007).

Some of identified factors that have contributed to students performance in Mathematics by scholars are teacher related factors such as shortage of qualified Mathematics teachers, poor teacher preparation, poor subject mastery, inappropriate method of teaching and teachers' poor disposition towards Mathematics (Adegoke, 2003; 
Adetunji, 2000). Others are students' related factors, such as poor background, anxiety, attitudinal problems, lack of interest in Mathematics, self-concept, poor study habits, poor assessment of memory ability, motivation, disadvantaged background, wrong techniques of solving problems, intellectual ability, failure to adhere to examination instructions, gender factor and insufficient preparation for Mathematics examinations (Esan, 1999; Ifamuyiwa, 1998; Olumuyiwa, 2012). There are also problems associated with techniques of teaching Mathematics (Akinsola, 1994; Odogwu, 2002; Ojo, 2009; Onobanjo, 2010; Oteyemi, 2001). Also included are school and society - related factors, such as inadequate instructional materials, and inadequate relevant Mathematics textbooks. Lastly, there are government factors (Akinsola, 1999; Oyedeji, 2000).

Certain factors should be considered before choosing any teaching strategy, Oyeniran (2003). Oluokun and Oyeniran (2006) discussed some of the criteria for choice of teaching methods. The criteria discussed were categorized according to their similarities under four factors. These are learner factors which include age, maturity, intellectual capability, learners' need, attitude and interest; teacher's factors such as qualification, experience, specialization, versatility on methods and attitude; School and subject -matter factors includes nature of the subject, topic and behavioral objective and Environmental factors which include class size, instructional materials, infrastructure and societal perception. On the quality of teachers based on their experience, Hanushek, Kain, and Rivin (2002) asserted that this is crucial schooling factor that explains difference in quality among schools.

There are some practices that lead to loss and anxiety in Mathematics in traditional conventional classroom settings. Those practices that usually lead to loss and anxiety in Mathematics are time deadline, imposed authority by teachers and public exposure (CurtainPhilips, 2011). As a result of this, there is a need to critically re-examine teaching strategies in classroom settings. Those teaching strategies that need more emphasis in Mathematics classroom settings are students' cooperation, problem solving and e-note Mathematics instruction (Ogochukwu, 2010). The fact that some students have anxiety in the traditional Mathematics classroom settings, there is a need for the teachers to map out teaching strategies that will make learning of Mathematics easier for the students' and also lead to better performance. Responses from students in Mathematics class that are incorrect should be handled with care in order to encourage students in learning and participation in Mathematics class.

Dennis (2005) study revealed that problem solving skill is the cornerstone to learning of Mathematics. Mathematics problems are presented to students to develop in them the potential for problem solving. The end result of mathematical problem solving is to arrive at a problem solution and while some other goals are to bring about new problem, coming up with new alternative solutions and interpretation of solution to a given problem or generalisation of results. Based on the Curriculum and Evaluation Standards for School Mathematics published by the National Council of Teachers of Mathematics, (1989) which was reviewed in (2007), advocates that a major goal for students' learning Mathematics are to become problem solvers with the aid of mathematical knowledge. Stanic and Kilpatrick (1988) recognized that Mathematics word problem concept has been in the curriculum as far back as 1650 B.C. Chris (2005) affirms that problem solving is like given a scenario that requires resolution usually in academic areas. Chris
(2005) explained the requirement of becoming a problem solver, which he further stressed that a problem solver must have a potential ability to bring about ways to solve a particularly problem totally. Chris (2005) also stressed that problem solving in Mathematics revolves around being giving a certain mathematical problem in which students require to interpret the problem on their own, map out a way or method to get it solve, follow certain mathematical rules or procedures to arrive to the result and then critically analyze the outcome or result to examine if the answer they get is in line with the problem presented.

Literate people in Mathematics see Mathematics as the same as solving problems-doing word problems, interpreting figures, creating patterns, proving theorems, developing geometric constructions, and so forth. Meanwhile, people who are not interested in Mathematics, will see all Mathematical activities as problem solving. Dennis (2005), described problem as a given situation, or critical description of certain thing in which one has no idea that vividly satisfies that description. He further stressed that a problem solver is someone who perceives and accepts a particular goal without having an immediate ways to arrive to the stated goal. He further explained that for anyone to become a problem solver there should be a specify goal, an hindrance to the attainment of that goal for the individual, and the acceptance by an individual of that goal for its actualisation. Whatever classifies as a problem for one learner may not be a problem for another and this can be as a result that there is no any hindrance to the attainment of such goal or no acceptance of such goal. Schoenfeld (2008) also noted that definition of problem is relative because it depends upon an individual. The main reasons for different studies on problem-solving in Mathematics of secondary school students as far back as 1960 can be found in the works of Polya (2009), who specialized in cognitive psychology, specifically, cognitive science. Postulation of theories of human learning are major focus of cognitive scientists and cognitive psychologists (Frederiksen, 1984), meanwhile, Mathematics educators put their effort to understand how students relates and interact with Mathematics (Schoenfeld, 2008).

According to Ogochukwu (2010), learning Mathematics requires serious personal effort from students because Mathematics is a complex task that puts a lot of demands on students. Teacher needs to encourage students because they need to be motivated if they will do well in the subject. It will be of benefit to Mathematics educators to come up with mode of instructional strategies that will improve students' interest in Mathematics and also stimulate them as well. Educators are making use of different types of educative software and multimedia that can be useful in the classroom presentation or activities in order to enhance teaching and learning (Tolhurst, 1995). The cognitive science has been particularly relying on computer simulations of problem solving (Adolphus \& Aderonmu, 2012). When a computer programme can be designed to bring about series of behaviour that is similar or the same with the series for human being, then such computer programme is called a theory or model of the behaviour. Adolphus and Aderonmu (2012) and Ken (2013) come up with simulations of mathematical problem solving which improves students understanding of problem solving in Mathematics. The basic mathematical activity is problem solving because the main focus of Mathematics educators is performance of students in line with educational stated objectives and students' abilities of becoming problem solver independently. Balogun (1982) had noted that mathematical application illustration and interrelation among object skills could be easily displayed by the learners through problem solving skills acquire via analytic powers. 
Polya (2009), suggested the procedures to engage students in problem-solving in Mathematics thus, introduce student to the problem, ability to collect important relationships about the problem given, identify and getting necessary requirement to arrive at the solution, critical examination of the basic requirement in relation to well proved solution and critical analysis. When students perception are acquired through hearing, seeing and doing are closely related to their critical thinking, then it is possible to lay good foundation for problem solving in Mathematics as it has been postulated by Jean Piaget theory (1896-1980) of cognitive development.

Study has shown that when teachers make use of concrete instructional materials in teaching theoretical concepts in Mathematics the students' problem solving abilities improved (Adolphus \& Aderonmu, 2012). The study also suggested the use of reflective thinking process after the students must have solved the problem. Based on this findings, effective teaching and good classroom environment can be possible considering students' learning styles, if students centered learning instructional presentation is adopted. True learning cannot take place if students do not mentally act upon information (by seeing, hearing, practicing), in such a way to understand and retain what he encounters. Problem solving concept in Mathematics has been regarded as a method of learning as well as outcome of learning (Akpan, 1987, Ubuz, 1984). Hence many terms like analytic, critical and reflective thinking, scientific method, discovery and inquiry have been used synonymously with problem solving (Akpan, 1987). For this reason, no two definitions of the concept have same connotation.

On interactive e-note Mathematics instructional strategy, Asiyai (2012), Gul and Yesilyurt (2011) affirmed that research evidences overwhelmingly support the claim that students learning improves when they interact with teaching materials and actively participate in their learning. There is need for Mathematics teachers to understand and promote teaching and learning activities that can facilitate and enhance learning in the classroom. Bayturan and kesan (2012); Gul and Yesilyurt (2011) further stressed that students have tendency to learn better if they were engaged in significantly appealing activities in Mathematics and Technology. The impact of Technology on aspect of education cannot be over-emphasised. The introduction of Information and Communication Technology (ICT) into teaching and learning, especially the products, has brought about an improvement in the content and the teaching methods. In general, ICT is in best position to bring about changes in pedagogical methods, increase access to quality education by individual and also bring changes to management in education system (Ikyumen \& Nwafor, 2013; Edith, 2013).

To educators, great excitement always comes as a result of creative presentation. Battulga, Koushi, Tamura and Moriguchi (2012) study revealed the effectiveness of interactive 3DCG to improve undergraduate medical students' achievement and motivation, meanwhile Battulga et al. (2012) in their study made use of e-class as support to instruction. Interactive e-note, which is imbedded in multimedia, involves combination of different digital media forms such as text, images, sound, and video, into an integrated multisensory interactive application or presentation to transmit information to an audience." It has strength to increase amount of information, couple with different types of information available to the learners. Students have tendency to build effective and accurate mental model far better than what they can do in text alone from the use of interactive e-note. Ogochukwu (2010) recent study revealed that students prefer attending classes where multimedia presentation is utilised because such classroom settings are usually interesting and exciting. Interactive enote provides great opportunities and challenges for teaching and learning Mathematics. Therefore, it is very important for Mathematics educators to improve their teaching style by critically examine the opportunities and challenges inherent in new technologies. Interactive e-note has different communication channel, each of which has its advantages and disadvantages. Velleman and Moore (1996) study revealed what needed to make interactive e-note effective, that is, different communication channels must be balance; using each of the channel for a specific purpose it is meant for and that no channel should dominates others. Video as one of channels has potential strength to make students see outside the classroom settings. Video attracts individual concentration via editing, and can also control available time and space via time-lapse, slow motion, microscopic, or telescopic views.

Video presentation will be fascinating once the tools of communication channels are used effectively. Animation is also part of communication channel of interactive e-note. When the objects display on the screen can change and move in the real time, then it is called animation. Studies have shown that animation, that is motion on the screen, is very crucial to hold learner attention because it plays a major role in interactive e-note design. Narration is number three of interactive e-note components. It looks as if those engineers of interactive e-note do not know the values of oral presentation when it comes to narration. An oral narrative has potential strength to captivate learners' attention when it is used along with animation and concise outlines of key points. The last component of an interactive e-note is sound. Sound has potential strength to improve the interactive e-note setting. Sound can provide meaning to animated objects or it can balance mood presentation that has turned out to be over serious. In another vein, sound improves retention of mnemonic morphs.

Study on the school type by Regina (2010) revealed that school type has significant effect on learners learning outcomes in Mathematics. The findings showed that the smaller class has direct correlation to enhancement of teaching and learning of Mathematics. In addition, some studies on school type revealed the effect of school type on school practices, and as well as differences between effective and ineffective schools. Secondary schools typologically can be private or public based on ownership. The public secondary schools are owned and financed by Federal Government while privately owned are financed by private individuals. According to Alimi, Ehinola and Alabi (2012) secondary schools are required to function and operate in accordance to national objectives of education irrespective of the ownership. Base on this fact, the quality of students output from secondary schools is determined by their good performance at the final external examinations because this is yardstick to determine school system effectiveness. School system is assumed to be effective if the students' performance is good (Philias and Wanjobi 2011). Cynthia and Megan (2008) study also argued that there is a relationship between facilities availability in quality term and students' academic achievement in Mathematics and English. It is general opinion in Nigeria that private schools have sufficient human and physical facilities, therefore, private schools students perform better than public school students. As a result of this, many parents prefer registering their children in private schools.. The current educational policy in the United States schools focused on market forces (Craig, 2010). This implies that education is seeing as market place where deregulation and competition in the market place will make experimentation, diversity, innovation and performance occurs at less 
expenses. This act of deregulation and competition in education sector will result in making quality education available to individuals irrespective of their status and disabilities. Milton Friedman (1955) in (Craig, 2010), also affirmed the philosophy behind school vouchers. This perceptive implies that competition for students, teachers, facilities, and funds will improve students' performance in schools and this will make school to produce students who are ready to learn and increase their scores in mathematics achievement tests. The competition among schools will improve performance and it will make those good schools to flourish and make those schools without standard to fail or improve on their standard if they will continue to exist. This competition among schools will improve general level of education in Nigeria. In free market economy, consumers are giving freedom of choice and they can move from between option. This encourages competition in the market and it also makes private enterprise to be more effective than public enterprise. This philosophy also is the same as Nigerian national identity of democratic freedom and free enterprise. A free market gives consumers the freedom of choice and free and fair society provides the platform to do so.

According to Craig (2010) the perceptive of a private or public in a free market makes school to be seen as a black box. There is no measure to determine if school performance is improved and why students' performance improved or not improving. It fails to explain how to improve teachers' lesson delivery or how changes in curriculum, facilities, class size, governance and administration might improve student performance. Rather, free market framework represents "invisible hand" postulated by Adam Smith and such mechanisms of invisible hand determines the students and school improvement (Craig, 2010). To get this done, private schools get students across different geographical boundaries and also remove all barriers of geographical or residential segregation that are very common to traditional public schools in Nigeria. Private schools reduce the need for desegregation measure because it gives parents and learners educational option that is very fascinating in which they will voluntarily draw to. Private schools provide instructional or curricular innovation or different educational opportunities that can draw students in. Besides, private schools provide a platform that is racially and economically diverse. Practically, private schools have some basic assumption that link learners interest with studies and also exposing learners to more diversity which may invariably improve students' academic achievement. This is quite different from the idea that pressures from competitive market will create improvement in both school and students' achievement. Although many research have been conducted to investigate if school type lead to students' academic performance (Bifulco \& Ladd, 2006; Esposito \& Cobb, 2008; Rouse \& Barrows, 2008), the findings are controversial because some studies reported that school type competition leads to improvement and while some studies find none. Many of these studies conducted are observational and the few experimental studies conducted yielded inconsistent results. Based on different studies on the school type, it has been noted that the school type influences students' achievement.

Singh and Imam (2013) also looked into the effect of institutional and personal variables on students' academic performance. This study was carried out in India in which the researchers investigated the effect of school climate, school type and medium of instruction on students' achievement in Mathematics. The total population sample was 1944 students which comprised 969 female and 975 males. Thirty six (36) schools from South-East Bihar in Indian. The researchers designed achievement test, school climate and attitudinal questionnaires to collect data from the respondents. The data collected were analysed using appropriate statistical instruments. The study showed that between male and female, there was significant relationship in their achievement in Mathematics. This implies that the males have good disposition to school climate and Mathematics better than their female counterpart. The reports of the findings also showed that students from school owned by federal government and private owned performed better in Mathematics than those schools owned by state government and minority managed schools. Additionally, the findings from this study showed positive correlation between school climate and students' performance. Positive relationship also exists between students disposition to Mathematics and students' achievement. Singh and Imam (2013) study examined school variables on how they interacted with other cognitive variables to predict achievement in Mathematics and it revealed specifically the effects of school variables on achievement of students in Mathematics.

Meremikwu and Enukoha (2010) investigated on how mathematics achievement of students influence by school type, that is, private and public, and also where the schools are located, that is, urban or rural. The study was conducted in the River state of Nigeria. The research design was quasi-experimental and six hundred students were selected for this study through multi-stage sampling technique. The main variables for this study were school location and school type. There are two groups in this study. One group exposed to the lesson with aid of instructional materials. The findings of this study revealed that learners achievement was not determined by gender but rather by whether school is private or public owned, treatment and school location. Interactions among the treatment, school type, school location and gender yielded statistical significant in describing learners' achievement. The findings revealed that learners in the urban areas from private schools performed better than learners from the public owned schools. Again, the mean scores differences between learners from private and public owned schools in mathematics were not significant. Finally, this study revealed better understanding on how instructional materials, school location and school type could play a critical role in improving students' achievement in Mathematics.

According to Craig (2010) some studies used local sample, which lead to limitation of external validity of such study. Quasi-experimental and observational studies are common research while experimental is rarely conducted. Many studies have focused on private schools while only few studies were conducted to compare school type and students' academic achievement. The main reasons for divers schools types include assumption that students' achievement is predicted by school type and that better school performance will result to better students performance (Craig, 2010; Lubienski \& Lubienski, 2008; Raudenbush, 2004; Regina, 2010). The reason for recent increase in demand for various school types and school choice is because of relationship that exists between students' achievement and school characteristics. The expected improvement can become a reality by assumption that market forces framework, relationship between curricular and students interest, diverse cultural environment, freedom of choice or various combination of all these can improve learning of Mathematics. Flaxman, Guerrero, and Gretchen (1997) findings revealed that there was no difference that was significant between large schools within city and comprehensive schools in achievement but there was a significant difference in the area of perceived parental support and parental attitude. Especially in this country, Nigeria, availability of teachers is 
strongly correlated with higher students' performance in Mathematics. According to Meremikwu et al. (2010) private schools have more of mathematics teachers' than public schools in Nigeria. Unavailability of Mathematics teachers in public schools makes teaching of the subject more difficult.

Gender is another moderating variable in this study beside the school type. Many researchers have looked into how students' achievement was influenced by gender in which there were different reports as regard gender influence on students' academic achievement. In study conducted by Okeke (2001) there was a significant gender difference between achievement in Mathematics and other science related subjects. Research have shown that the average scores of students' achievement in Mathematics favours of male students (Abiona, 2008; Aremu, 2005; Bilesanmi-Awoderu, 2002; Ojo, 2009; Olaleye, 2004); occasionally in support of female students (Olatundun, 2008) and many studies also showed that both achievement and attitudes of students were not influenced by gender differences in sciences and Mathematics (Oduwaye, 2009; Okoye, 2010; Owoyemi, 2007; Raimi \& Adeoye, 2002). Many research showed that there was significant difference between female and male students in favour of female students (Bolorunduro, 2005). According to Aremu and John, 2005 the way forward to close the gap that exists between female and male achievement in mathematics is an ongoing research. Gender is an issue receiving the attention of different researchers in the world (UNESCO, 2004).

Therefore, to improve free and human development there is a need to close the gap between male and female achievement in mathematics. One of the concurrent global problems is issue of gender inequality in education (Bordo, 2001; Reid, 2003; UNESCO, 2004). In a study conducted by Abiam and Odok (2006) there was no relationship that was significant between gender and achievement in some mathematics concepts. The finding also revealed that there was not a strong difference in performance of male and female students in trigonometry and geometry. Some people believed that Mathematics is for the male students and this statement may also widen the gap between male and female students' achievement in Mathematics (Mutemeri \& Mygweni, 2005). Campbell and Storo (1996) investigated differences that exist in mathematics achievement between gender and their study revealed that there are some folklore that have been generally assumed to be true. Such myth is that men are quantitatively inclined while women are qualitatively inclined. The meaning of this belief is that girls are not suitable to go into any Mathematics-related career such as physical sciences and engineering. Meanwhile Millennium Development Goals (MDGs) sets to put an end to gap that exists between male and female at Basic and Secondary Education by year 2015.

Gender inequality requires more attention. Students' achievement in Mathematics usually attributed to gender differences. Kyei, Apam and Nokoe (2011) compared the level of attention the teacher gives to female students and male students in mathematics classroom. A study also affirmed that male will still continue dominating mathematics and science related field (Olaleye, 2004). The students' expectation for success and attitudes determine students' differences in achievement in Mathematics not in their gender abilities (Kyei, Apam, \& Nokoe, 2011) Evidently, society attitude brings about many problems but the most detrimental aspect of it is that female students do not recognize their own personal potential and this does not limit them only in the classroom but also limit them in the choice of their future career
(Olaleye, 2004). Additionally, many associate male achievement in Mathematics with male gene. Again, parents and teachers do not have much expectations for the females in science and Mathematics in comparison to high expectation for the males. Again, based on this fact, gender stereotypes were recognized as one of social factors by some Mathematics orientation models. Gender stereotypes that many teachers belief in and the students also absorbed affect the future of the female students' achievement in Mathematics (Banaji, Greenwald, \& Nosek, 2002; Olaleye, 2004). Both female and male students have inbuilt potential ability to learn skills that are embedded in Mathematics and are born interested in variety of objects and ideas (Spelke, 2005; Spelke \& Grace, 2007). Gender as a moderating variable therefore attracted further investigation in this study because of the conflicting nature of results as revealed in the above researches that focus on gender and Mathematics. This variable was used in this study to bring about consistent evidence on the influence of this factor of gender on achievement and attitude through the use of interactive e-note Mathematics instruction and problem solving strategy in learning mathematical concepts.

\section{Statement of the Problem}

Mathematics serves as the bedrock for the development of science and technology, but many students perform poorly in it on yearly basis in public examination. This trend has been attributed to usage of ineffective instructional strategies by the teachers. Therefore, scholars have suggested adoption of instructional strategies that are capable of making students interact with technology and be a good problem solver while learning Mathematics; develop ability to link their past experiences with new ideas. Some of the strategies proposed and used in teaching Mathematics include concept mapping, personalization approach, mastery learning and cooperative instructional strategy. Extant literature has documented the effectiveness of these strategies on students' achievement in several school subjects. The use of e-note has not been well- researched especially at the Junior Secondary School level. This study, therefore determined the effects of Interactive e-note instructional strategy and Problem-solving strategy on junior secondary school achievement in Mathematics in Kaduna, Nigeria, while the moderating effect of school type and gender were also examined.

\section{Hypotheses}

The following null hypotheses were tested at 0.05 level of significance.

$\mathrm{H}_{0} 1$ : There is no significant main effect of treatment on students achievement in Mathematics;

$\mathrm{H}_{0}$ 2: There is no significant main effect of school type on students achievement in Mathematics;

$\mathrm{H}_{03}$ : There is no significant main effect of gender on students achievement in Mathematics;

Ho4: There is no significant interaction effect of treatment and school type on students 'achievement in Mathematics;

Ho5: There is no significant interaction effect of treatment and gender on students' achievement in Mathematics;

$\mathrm{H}_{06}$ : There is no significant interaction effect of school type and gender on students' achievement in Mathematics;

$\mathrm{H}_{0} 7$ : There is no significant interaction effect of treatment, school type and gender on student achievement in Mathematic 


\section{METHODOLOGY}

\section{Research Design}

This study adopted the pretest-posttest control group quasiexperimental design involving a $3 \times 2 \times 2$ factorial matrix. The design had treatment at 3 levels crossed with the student's school type at two levels (private, public) and gender (male, female) at two levels. The design is represented thus:

$\begin{array}{lll}0_{1} \mathrm{X}_{1} \mathrm{O}_{4} & - & \text { Experimental Group 1 } \\ 0_{2} \mathrm{X}_{2} \mathrm{O}_{5} & - & \text { Experimental Group 11 } \\ \mathrm{O}_{3} \mathrm{X}_{3} \mathrm{O}_{6} & - & \text { Control Group }\end{array}$

Where $0_{1}, 0_{2}$ and $0_{3}$ represent the pretest for two experimenter groups and a control group and $0_{4}, 0_{5}$ and $0_{6}$ represent the posttest for the experimental and control groups.

i. $\quad X_{1}=$ represents Treatment 1 for group 1 involving Interactive e-note Mathematics Instruction Strategy (IMIS)

ii. $\mathrm{X}_{2}=$ represent Treatment 11 involving Problem solving instructional Strategy (PSS)

iii. $\mathrm{X}_{3}=$ represent control group involving the use of Conventional Teaching Strategy (CTS)

Population: A total of $400 \mathrm{Js}$ (1) students selected from three private and three public schools within two purposively selected local government areas in Kaduna State took part in the study

\section{Research Instruments}

The following research instruments were used in the study

1. Mathematics Achievement Test (MAT)

2. Interactive e-note Mathematics Instruction Strategy (IMIS)

3. Instructional Guide for Problem Solving Strategy (IGPSS)

4. Instructional Guide for Conventional Teaching Strategy (IGCTS)

5. Teachers Evaluation Sheet (TES) for:

a. Interactive e-note Mathematics Instruction (IMIS)

b. Problem Solving Strategy (IGPSS).

c. Conventional Teaching Strategy (IGCT)

6. Validation Sheet (VS) for Interactive e-note Mathematics Instruction Strategy (IMIS)

\section{Data Collection}

The cooperation and support of the teachers and school principals were sought. The researcher discussed with Mathematics teachers in the six schools involved and told them that the students should not be notified that they are been used for the study. The administration of pretest (Mathematics Achievement Test) then followed. JS1 Mathematics teachers from each of the six schools were given training in the use of strategies appropriate for their group for two weeks. From the two local government selected for this study, one private and one public schools was randomly selected for each of the strategy in the study. Hence each Local Government Area represented each of the groups that is interactive e-note Mathematics instructional strategy, problem solving instructional strategy and conventional teaching strategy.

The teachers for experimental group I was provided with interactive Mathematics e-note package prepared by the researcher for installation into the students lap top/ school server. While the teachers for experimental group II were provided with the problem solving instructional package guide. The teachers for the control group also received prepared guide for the conventional teaching strategy having the same contents as in the two experimental groups. Since the classes were handled by the teachers the students believed that they were receiving their normal lesson. After the administrations of the pretest and necessary materials had been given to the teachers, the teaching commenced and lasted 8 weeks. At the end of the instruction, the pretest instruments were used as posttest to all groups to measure the learning outcomes that had taken place. The experiment covers a total of 12 weeks.

\section{Method of Data Analysis}

The data were analysed using descriptive statistics and the hypotheses formulated were tested at $\mathrm{p} \leq 0.05$ using Analysis of Covariance, Bonferrroni post hoc test and estimated marginal mean.

\section{RESULTS AND DISCUSSION}

The results in this study are presented and discussed in line with the formulated hypotheses.

\section{Presentation of Results}

Hypothesis 1a: There is no significant main effect of treatment on students' achievement in Mathematics

Table 3 shows that treatment had a significant main effect on students 'achievement in Mathematics $\left(\mathrm{F}(2,385)=7.01 ; \mathrm{p}<0.05 ; \eta^{2}=0.04\right)$. Therefore, the null hypothesis $1 \mathrm{a}$ is rejected. This indicates that the treatment had main effect, that is, significant on achievement of students in Mathematics and this comes with $4.0 \%$ effect size. In order to determine the direction of significance, Estimated marginal means and Bonferroni post hoc analysis was computed for the pair wise comparison of the posttest achievement mean score of the treatment groups.

Table 4 shows that students exposed to interactive e-note instructional strategy had the highest posttest achievement mean score $(\bar{x}=21.48)$ followed by those exposed to the conventional instructional strategy $(\bar{x}=20.42)$ and the least posttest mean score was obtained by those exposed to problem solving strategy $(\bar{x}=20.30)$.

Table 5 shows that the posttest achievement mean score for those students who were taught through interactive e-note strategy was significantly different from those exposed to conventional instructional strategy and problem solving instructional strategy respectively. On the other hand, the posttest achievement mean scores of students exposed to conventional instructional strategy was not significantly different from those exposed to problem solving instructional strategy. This could be noted from Table 3 that showed the significant main effect of the treatment that was due to the posttest achievement mean scores of students exposed to the interactive e-note.

Hypothesis 2: There is no significant main effect of school type on students Achievement in Mathematics

Table 3 shows that there was a significant main effect of school type on students' achievement in Mathematics $(F(1,385)=27.63 ; \mathrm{p}<0.05$; $\left.\eta^{2}=0.067\right)$, hence the null hypothesis 2 is rejected. This means that there is effect size of $6.7 \%$ due to main effect of school type on students' achievement in Mathematics that is significant. In order to determine the direction of significance an estimated marginal mean was computed in Table 6. 
Table 3. Analysis of Covariance of Achievement by treatment, school type and gender

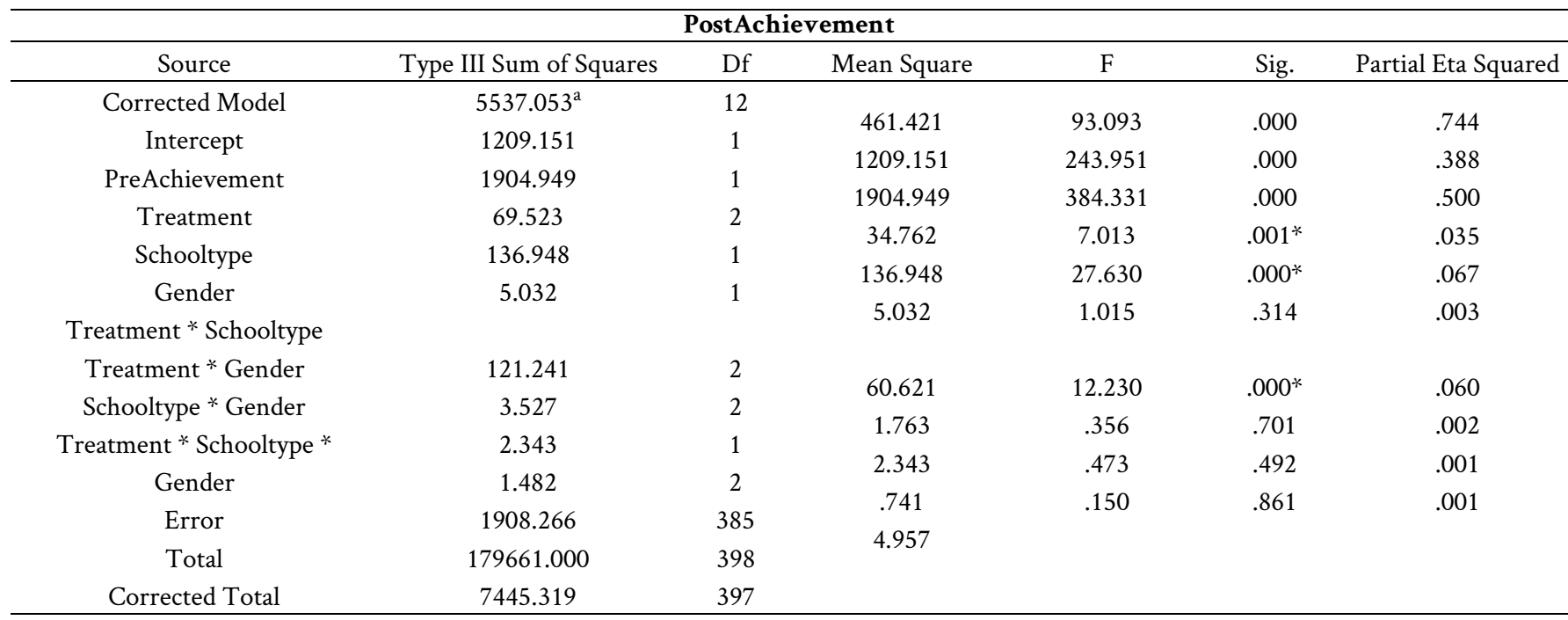

a. R Squared $=.744$ (Adjusted R Squared $=.736){ }^{*}$ depict significant at 0.05 level of significance

Table 4. Estimated marginal means of Mathematics posttest achievement according to treatment

\begin{tabular}{|c|c|c|c|c|}
\hline \multicolumn{5}{|c|}{ Post Achievement } \\
\hline \multirow{2}{*}{ Treatment } & \multirow{2}{*}{ Mean } & \multirow{2}{*}{ Std. Error } & \multicolumn{2}{|c|}{ 95\% Confidence Interval } \\
\hline & & & Lower Bound & Upper Bound \\
\hline Interactive e-note & $21.481^{\mathrm{a}}$ & .213 & 21.062 & 21.901 \\
\hline Problem Solving & $20.299^{a}$ & .218 & 19.870 & 20.728 \\
\hline CIS & $20.415^{\mathrm{a}}$ & .222 & 19.978 & 20.852 \\
\hline
\end{tabular}

a. Covariates appearing in the model are evaluated at the following values: PreAchievement $=15.6382$

Table 5. Bonferonni Pairwise Comparison of the treatment groups

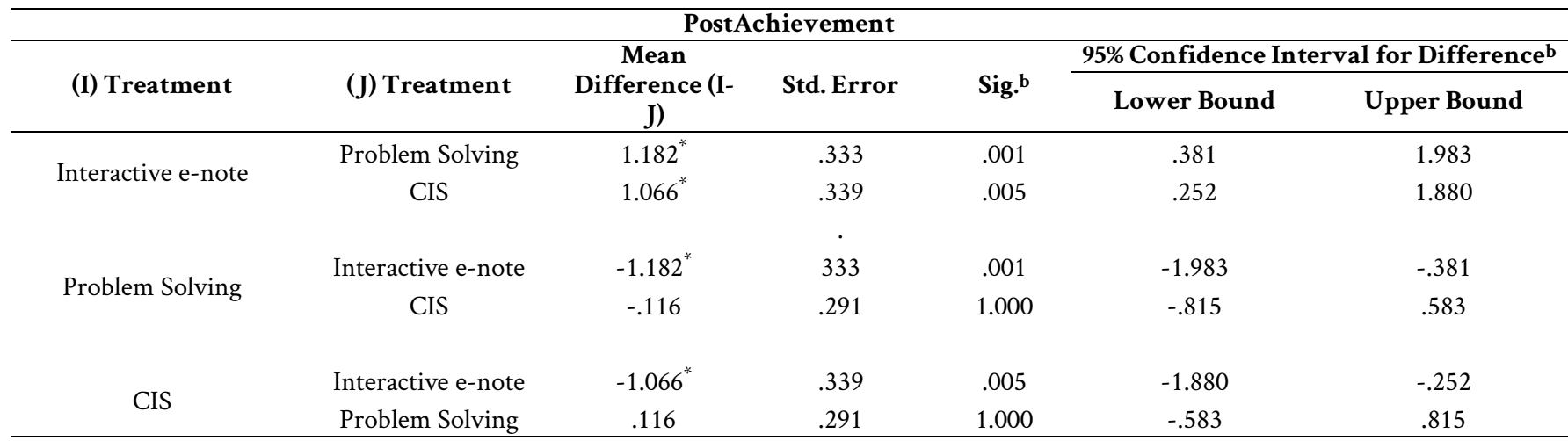

Based on estimated marginal means

*. The mean difference is significant at the .05 level.

b. Adjustment for multiple comparisons: Bonferroni

Table 6. Estimated Marginal Means of Students Achievement in Mathematics According to School Type

\begin{tabular}{cccc}
\hline \multirow{2}{*}{ School type } & \multirow{2}{*}{ Mean } & \multirow{2}{*}{ Std. Error } & \multicolumn{2}{c}{ 95\% Confidence Interval } \\
\cline { 3 - 4 } Public & $20.078^{\mathrm{a}}$ & .173 & Lower Bound \\
Private & $21.385^{\mathrm{a}}$ & .164 & 19.738 \\
\hline
\end{tabular}

a. Covariates appearing in the model are evaluated at the following values: PreAchievement $=15.6382$.

Table 6 shows that the Mathematics achievement posttest mean scores of students in the private school $(\bar{x}=21.39)$ is higher than that of their counterpart in public school $(\bar{x}=20.08)$. It can therefore be inferred that the significant main effect of school type is due to the Mathematics achievement posttest mean score of the students in the private school.
Hypothesis 3: There is no significant main effect of gender on students achievement in Mathematics

Table 3 shows that there is no significant main effect of gender $\{F(1,385)=1.02 ; p>0.05\}$ on students' achievement in Mathematics. Based on this result, the null hypothesis 3 is not rejected. This means that there is no significant main effect of gender on Mathematics achievement of students. 
Table 7. Estimated marginal means of posttest achievement according to treatment and school type

\begin{tabular}{cccccc}
\hline Treatment & \multirow{2}{*}{ School type } & \multirow{2}{*}{ Mean } & \multirow{2}{*}{ Std. Error } & \multicolumn{2}{c}{ 95\% Confidence Interval } \\
\cline { 5 - 6 } Interactive e-note & Public & $21.519^{\mathrm{a}}$ & .255 & 21.018 & Upper Bound \\
& Private & $21.444^{\mathrm{a}}$ & .314 & 20.826 & 22.020 \\
\multirow{2}{*}{ Problem Solving } & Public & $19.597^{\mathrm{a}}$ & .307 & 18.993 & 20.061 \\
& Private & $21.002^{\mathrm{a}}$ & .293 & 20.426 & 21.578 \\
CIS & Public & $19.119^{\mathrm{a}}$ & .326 & 18.477 & 19.761 \\
& Private & $21.711^{\mathrm{a}}$ & .291 & 21.139 & 22.283 \\
\hline
\end{tabular}

a. Covariates appearing in the model are evaluated at the following values: PreAchievement $=15.6382$.

Hypothesis 4: There is no significant interaction effect of treatment and school type on student' achievement in Mathematics

Table 3 shows that there was a significant interaction effect of treatment and school type $\left(\mathrm{F}(2,385)=12.23 ; \mathrm{p}<0.05 ; \mathrm{n}^{2}=0.06\right)$ on students' achievement in Mathematics. Based on this result, the null hypothesis 4 is rejected. This reveals that there is a significant interaction effect of treatment and school type on students' achievement. This implies that the treatment is sensitive to the school type. In order to understand the direction of significance and which school type benefited more in the treatment groups, estimated marginal mean was computed.

Table 7 shows that students exposed to problem solving $(\bar{x}=21.00)$ and Conventional instructional strategy $(\bar{x}=21.71)$ in private school had a higher posttest achievement mean scores in Mathematics than their counterparts in public schools. It was only in the interactive e-note that the public schools had a slightly higher achievement mean scores than the private. This might probably be because of the innovativeness of the e-note instructional strategy.

Hypothesis 5: There is no significant interaction effect of treatment and gender on student' achievement in Mathematics

The result in Table 3 shows that there is no significant interaction effect of treatment and gender on students' achievement in Mathematics $(\mathrm{F}(2,385)=.356 ; \mathrm{p}>0.05)$. Therefore, the null hypothesis 5 is not rejected. This implies that the interaction effect of treatment and gender on students' achievement in Mathematics is not significant.

Hypothesis 6: There is no significant interaction effect of school type and gender on student' achievement in Mathematics

The result in Table 3 shows that there is no significant interaction effect of school type and gender on students' achievement in Mathematics $(F(1,385)=.473 ; p>0.05)$. Therefore the null hypothesis 6 is not rejected. This implies that the interaction effect of school type and gender on students' achievement to Mathematics is not significant

Hypothesis 7: There is no significant interaction effect of treatment, school type and gender on student' achievement in Mathematics

The result in Table 3 shows that there is no significant interaction effect of treatment school type and gender on students' achievement in Mathematics $([\mathrm{F}(2,385)=0.150 ; \mathrm{p}>0.05)$. Therefore, the null hypothesis 7 is not rejected. This implies that the interaction effect of treatment, school type and gender on students' achievement in Mathematics is not significant.

\section{Discussion of Findings}

\section{Main effect of treatment on achievement in mathematics}

The findings of this study showed that the main effect of treatment on students' mathematics achievement is significant and this main effect is largely due to the posttest achievement of those students who were exposed or taught through the interactive e-note instructional strategy. This is probably as a result of the learners' interest and excitement which the strategy aroused among students exposed to it. The strategy also allows a great deal of interaction among the students. The findings of this study on achievement corroborates that of Sara (2012) who found that college students taught by interactive multimedia had greater long - term retention compared to students taught by traditional classroom methods. Sara (2012) also established that, the students learning with help of the interactive e-note fared better in Mathematics than the students learning through the conventional instructional strategy. Also the results of this study in agreement with that of Battulga, Koushi, Tamura and Moriguchi (2012) which showed that the interactive 3DCG model is effective in undergraduate medical education in terms of achievement and enhanced the motivation of medical students; although Battulga etal (2012) used interactive e-class as a supplement to instruction

\section{Main effect of school types on achievement in mathematics}

The result of the findings showed that the main effect of the school type on students' achievement in Mathematics is significant. This main effect was in favor of students in the private school. Perhaps, most of the private schools in this study had a very good achievement in their pretest scores in Mathematics achievement test. As a result of this they already have a better previous knowledge of the topics they were taught in Mathematics. This is in agreement with the findings of Chubb and Moe (1990), Coleman and Hoffer (1987), and Coleman (1982) confirm that those students in private schools usually have better achievement than those students from public schools when socioeconomic status was given consideration in their study. This finding is not in line with the findings of Lubienski and Lubienski (2006) which found out that there is slight better achievement of public schools students in Mathematics over private schools students for those who are located in the same similar geographical environment

\section{Main effect of gender on achievement in mathematics}

The findings of this study revealed that main effect of gender on students' achievement in Mathematics is not significant. This implies that being a male or a female does not give learner advantage in terms of achievement in Mathematics. The findings of this study is in line with that of Owolabi and Etuk-Iren (2014) which revealed that gender differences have nothing to do with students achievement in mathematics in college of education. Also, the findings of this study is also in line with that of Lindberg, Hyde and Petersen (2010) who found out in a metal analysis of 242 studies between 1990 and 2007 representing the testing of $1,286,350$ and equal variance was found among male and female. In the same vein, the findings of the study 
revealed that main effect of gender on students' attitude to Mathematics was not significant.

\section{Interaction effect of treatment and school type on achievement in mathematics}

The result from the findings of this study revealed that interaction effect of treatment and school type on students' achievement in Mathematics was not significant. The matrices in Tables 6 and 7 shows that students in private school in the control and the problem solving treatment groups were having better achievement in comparison with their peer in the public schools. This could be so due to the fact that private school students in these treatment groups had a better background in Mathematics than their colleagues in public schools as indicated in the comparison of their posttest scores. On the other hand, students in public schools exposed to the interactive e-note instructional strategy had a slightly better achievement mean score than those in the private schools. The only treatment which made the public students do better than private was the interactive e-note. This implies that the achievement deficit of the public schools students in Mathematics can be bridged through an interactive e-note instructional strategy. The finding of inferred that the students attitude to Mathematics can be influenced through significant interaction effect that occurs between treatment and school type.

\section{Interaction effect of treatment and gender on achievement in to mathematics}

The result of the finding makes it known that the interaction effect of treatment and gender on students' achievement in Mathematics is not significant. This means that the treatment worked effectively on male and as well as female students. The finding of this study corroborates the findings of Leder (1982), Eccles and Blumenfeld (1985), and Koehler (1990) that there is no doubt the way teacher treated each students based on their gender has direct influence on gender differences in achievement in Mathematics. The finding of the study also agrees with that of Abonyi, Maduagwuna, Ugamma (2014) which established that interaction of teaching method and gender on junior secondary two achievement in quadratic expression was not significant. The findings of this study however deviates from the findings of Oladayo (2012) which showed that there is a significant interaction of gender and teaching methods on students achievement in Mathematics.

\section{Interaction effect of school type and gender on achievement in mathematics}

The findings indicated that interaction effect of school type and gender on the achievement of students in Mathematics was not significant. This implies that the type of school the students attended do not in any way affect the achievement of both male and female students in Mathematics.

\section{Interaction effect of treatment, school type and gender on achievement mathematics}

The findings of this study revealed that the interaction effect of treatment, school type and gender on the achievement of students in Mathematics was not significant. This implies that the type of school and the gender of students does not in any way hinders or give any advantage to the potency of the treatment on students' achievement. The treatment was effective among male and female students in private school as it is among the male and female students in public schools.
Author contributions: All authors were involved in concept, design, collection of data, interpretation, writing, and critically revising the article. All authors approve final version of the article.

Funding: The authors received no financial support for the research and/or authorship of this article.

Declaration of interest: Authors declare no competing interest.

Data availability: Data generated or analysed during this study are available from the authors on request.

\section{REFERENCES}

Abakpha, B. O., \& Agbo-Egwu, A. O. (2008). The effect of small group cooperative learning on students achievement and retention in Mathematics tests. Benue Journal of Research of Science Education, 1(1), $71-80$.

Abakpha, B. O., \& Iji, C. O. (2011). Effect of mastery learning approach on Senior Secondary School Students achievement in geometry. Journal of Science Teachers Association, 46(1), 207-223.

Abiam, P. O., \& Odok, J. K. (2006). Factors in Students' achievement in different branches of secondary school Mathematics. Journal of Education and Technology, 1, 161-168.

Abiona, O. F. (2008). Effects of three modes of instruction on students environmental knowledge, attitudes and skills in solid wastes and sewage management in Biology (Ph.D. Thesis). Department of Teacher Education, University of Ibadan.

Abonyi, O. S., Maduagwuna, N., \& Ugana, J. O. (2014). Effect of Mathematical Game on Students Achievement in Quadratic Expressions. International Journal of Scientific and Engineering Research, 1(6), 678-684.

Adegoke, A. B. (2003). Teacher influence as a determinant of dependentprone students' learning outcomes in SSS Geometry in Ibadan, Nigeria (Unpublished Ph.D Thesis), University of Ibadan.

Adetunji, F.O. 2000. A study of some Nigerian primary school teachers' attitude to Mathematics. African Journal of Educational Research, 6(1 and 2), 93-99.

Adolphus, T., \& Aderonmu, T. S. B. (2012). Comparative analysis of problem-solving ability among JSS Mathematics students using computer-assisted instruction blended with problem-solving approach (CAI-PS) versus traditional teaching approach (TTP) in teaching basic statistics. American Journal of Scientific and Industrial Research, 3(2), 81-85. https://doi.org/10.5251/ajsir.2012.3.2.81.85

Akinsola, M. K. (1994). Comparative effects of mastery learning and enhanced mastery learning strategies on students' achievements and selfconcept in Mathematics (Unpublished Ph.D. Thesis), University of Ibadan.

Akinsola, M. K. (1999). Factors inhibiting the learning of Mathematics. Evaluation of Africa. In J. O. Obemeata, S. O. Ayodele, \& M. A. Araromi (Eds.), Evaluation in Africa in Honour of Yoloye (pp.175182). Edo: Stiring-Horden Publishers Ltd.

Akinsola, M. K., \& Awofala, A. O. (2009). Effects of personalization of instruction on students achievement and self efficacy in Mathematics word problems. International Journal of Mathematical Education in Science and Technology, 40(3), 389-404. https://doi.org/10.1080/00207390802643169 
Akinsola, M. K., \& Ifamuyiwa, S. A. (2008). Improving senior secondary school students attitude towards mathematics through self and cooperative - instructional strategies. International Journal of Mathematical Education in Science and Technology, 39(5), 569-585. https://doi.org/10.1080/00207390801986874

Akpan, A. A. (1987). Correlate of Mathematics Problem Solving ability among Secondary School Students in Cross River State of Nigeria (Unpublished Ph.D. Thesis), University of Ibadan.

Alechenu, J. ((2012). We need Maths for Nigeria to Develop-Ale. The Punch. Retrieved from https://punchng.com/education/we-needmaths-for-nigeria-to-develop-ale/\#

Alimi, O. S., Ehinola, G. B., \& Alabi, F. O. (2012). School type facilities and Academic Performance of students' in senior secondary schools in Ondo State, Nigeria. Journal of International Education Studies, 5(3), 44-48. https://doi.org/10.5539/ies.v5n3p44

Amao, F. A. (2015). Psychological Variables as Predictors of Pre-service Teachers' Achievement in Mathematics and Attitude to Mathematics Teaching in South- West, Nigeria (Unpublished Ph.D. Thesis), University of Ibadan.

Amao, S. A., \& Disu, A. B. (2012). School Environment factors and Mathematics Teaching Effectiveness, Implication for E-learning. Library Philosophy and practice (e-journal), Paper 837. Retrieved from http://digitalcommo.s.unl.edu/libphi/prac/837

Aremu, A., \& John, A. (2005). Gender implication of the use of video drama in environmental education. Isssues in language communication and education. A book in honour of C. A. Okedara, D. A. Akinbade, \& C. O. O. Kolawole (Eds) (pp. 342-352). Ibadan: Constellation books.

Asiyai, A. A. (2012). Strategies for enhancing the instructional performance of secondary school science teachers. Nigerian Journal of Curriculum and Instruction, 19(1), 42-46.

Awofala, A. O. A. (2011). The effect of concept mapping strategy on students' achievement in Junior Secondary Mathematics. International Journal of Trends and Technology, 2(3), 11-16.

Balogun T. A. (1982). Improvisation of science teaching equipment. Journal of Science Teachers Association of Nigeria, 2(2), 131-137.

Banaji, M. R., Greenwald, A. G., \& Nosek, B. A. (2002). Math=male, $\mathrm{me}=$ female, therefore math=me. Journal of Personality and Ssocial Psychology, 83, 44-59. https://doi.org/10.1037/0022-3514.83.1.44

Battulga, B., Konishi, T., Tamura, Y., \& Moriguchi, H. (2012). The effectiveness of an Interactive 3-Dimensional Computer Graphics Model for Medical Education. Interactive Journal of Medical Research, 1(2), e2. https://doi.org/10.2196/ijmr.2172

Bayturaum, S., \& Kesan, C. (2012). The effect of computer assisted instruction in the achievement and attitude towards Mathematics of students in Mathematics Education. International Journal of Global Education, 1(2), 42.

Beans, A. (2008). The importance of Mathematics. Me or My Maths. In L. Benveniste, M. Carnoy, \& R. Rothstein (Eds.), All Else Equal: Are Public and Private Schools Different? New York: Routledge Falmer.

Bifulco, R., \& Ladd, H. F. (2006). The impact of charter schools on student achievement: evidence from North Carolina. Education Finance and Policy, 24(2), 133-147. https://doi.org/10.1162/ edfp.2006.1.1.50
Bilesanmi-Awoderu, J. B. (2002). The status of Biology practical skills acquisition among Nigerian secondary senior schools in Ogun state. African Journal of Educational Research, 8(1 and 2), 1-7.

Bolorunduro, O. M. (2005). The impact of the instructional strategies of the Nigerian integerated science teacher education project on students' learning outcomes at junior secondary school level (Ph.D. Thesis), Department of Teacher Education, university of Ibadan.

Bordo, S. (2001). Selection from the flight to objectivity. In M. Lederman, \& I. Barrtsh (Eds.), The Gender and science reader. London: Routledge.

Bruner, J. S. (1961). The act of discovery. Harvard Educational Review, $31,21-32$.

Campbell, P. B., \& Storo J. N. (1996). Girls are...boys are...: Myths, stereotypes, and gender difference. Office of Educational Research and Improvement, U.S. Department of Education. Retrieved from http://www.as.wvu.edu/wmst245/AdobeFiles/BoyGirlDifference s2.pdf

Chris, S. (2005). Problem solving-elementary level EPSY400 classroom learning. Retrieved from http://www.moodle.ed.uiuc.edu/wiked/ index.php/ Problem_solving-Elementary_level

Chubb, J. E., \& Moe T. M. (1990a). America’s Public Schools: Choice Is a Panacea. Brookings Review, 8(3), 4-12. https://doi.org/10.2307/ 20080159

Chubb, J. E., \& Moe, T. M. (1990b). Politics, Markets, and America's Schools. Washington, DC: Brookings Institution.

Coleman, J. S., \& Hoffer, T. (1987). Public and Private High Schools: The Impact of Communities. New York: Basic Books.

Curtain-Phillips, M. (2001). The causes and prevention of math Anxiety. Math Goodies.

Cynthia, U., \& Megan, T. (2008). The Walls Speak: the interplay of quality facilities, school climate, and student achievement. Journal of Educational Administration, 46(1), 55-73. https://doi.org/10.1108/ 09578230810849817

Davies, S., \& Quirke, L. (2004). The new institutionalism, market theory, and private schools: How institutions shape choice [Paper Presentation]. Annual meetings of the American Sociological Association, August, San Francisco.

Delvin, K. (2009). Achieve for the Mathematics: The Science of pattern's category. Mathematics for real reason?. Retrieved from http://www.teachildmathematics.com/wordpress/?Categoryname $=$ Mathematics

Dennis, E. C. (2005). The development of problem solving abilities and strategies to facilitate their attainment. Retrieved from http://home.southernct.edu/ dennise1/qualfyex.htm

Eccles, J. S., \& Blumenfeld, P. (1985). Classroom experiences and student gender: Are there differences and do they matter? In L. C. Wilkinson, \& C. B. Marrett (Eds.), Gender influences in classroom interaction. New York: Academic Press. https://doi.org/10.1016/ B978-0-12-752075-9.50010-6

Edith, E. C. (2013). The role of information and communication technology in enhancing effective instructional delivery in tertiary institutions. Journal of Educational Media and Technology, 17(1), 7583. 
Esan, A. O. (1999). Effects of Cooperative and Groupistic problem - solving strategies on students' learning outcomes in secondary school Mathematics (Unpublished Ph.D Thesis), University of Ibadan.

Esposito, C., \& Cobb, C. (2008). Estimating the School-Level Effects of Choice on Academic Achievement in Connecticut's Magnet, Technical, and Charter Schools [Paper Presentation]. American Education Association Annual Meeting.

Eze, J. E. (2007). Mathematic education for job creation: Implication for tertiary education. ABACUS Journal of Mathematical Association of Nigeria, 32(1), 45-153.

Federal Republic of Nigeria. (2004). National Policy in Education. Lagos: NERDC Press.

Flaxman, E., Guerrero, A., \& Gretchen, D. (1997). Career Development Effects of Career Magnets versus Comprehensive Schools. Berkeley, CA: National Center for Research in Vocational Education.

Frederiksen, N. (1984). Implications of cognitive theory for instruction in problem solving. Review of Educational Research, 54, 363-407. https://doi.org/10.3102/00346543054003363

Gagne, R. (1965). Conditions of Learning. Holt, Rinehart \& Winston Ltd.

Gagne, R., Briggs, L. \& Wager, W. (1992). Principles of Instructional Design (4th Ed.). Fort Worth, TX: HBJ College Publishers.

Gonzales, N., Andrade, R., Civil, M., \& Moll, L. (2001). Bridging funds of distributed knowledge: creating zones of practices in Mathematics. Journal of Education for Students placed at Risk, 6(1 and 2), 115-132. https://doi.org/10.1207/S15327671ESPR0601-2_7

Gouba, L. (2008). The importance of Mathematics in everyday life. African Institute for Mathematical Sciences, South Africa.

Gul, S., \& Yesilyurt, S. (2011). The effect of computer assisted constructivist learning approach on students attitudes and achievements. Electronic Journal of Science and Mathematics Education, 5(1), 94-115.

Gutstein, E., \& Peterson, B. (Eds). (2005). Rethinking Mathematics: teaching social justice by the numbers. Milwaukee, WI: Rethinking Schools, Ltd.

Hanushek, E., Kain, J., \& Rivkin, S. (2002). Teachers, schools and academic achievement. Working paper No. 6681. Cambridge: National Brueau of Economic Research.

Ifamuyiwa, A. S. (1998). Correlates of academic performance in secondary school Mathematics. Studies in curriculum, 2, 30-38.

Ikyumen, I. M., \& Nwafor, O. (2013). Mediated environment and distributed cognition as aframework for modeling ict integration in science, technology and Mathematics education in Nigeria secondary school education. Journal of Educational Media and Technology, 17(1), 111-118.

Jain, P. (2010). Mathematics queries. The role of Mathematics in other disciplines. Retrieved from http://drpjain-mathproblems. blogspot.com/2010/03/role-of-mathematics-in-other.html

Jegede, O. (2011). Hong kong. In O. Jegede, \& G, Shive (Eds.), Open and distance education in the Asia Pacific Region (pp. 44-79). Hong Kong: Open University of Hong Kong Press.

Kaino, L. M. (2015). The use of computers in learning: A case study of selected Botswana Junior secondary school. Retrieved from www.Kaino.pdf
Ken, H. (2013). Helping Students Develop Expertise in Problem Solving while learning physics. Retrieved from http://www.aapt.org/conference/ newfaculty/..../Heller_une_2013_problem_solving.pdf

Koehler, M. S. (1990). Classrooms, teachers and gender differences in Mathematics. In E. Fennema, \& G. Leder (Eds.), Mathematics and Gender. New York: Teachers College Press.

Kyei, L., Apam, B. K., \& Sagary Nokoe, K. S. (2001). Some gender difference in performance in senior high Mathematics examination in mixed high schools. American Journal of Social and Management Sciences, 2(4), 348-355. https://doi.org/10.5251/ajsms.2011.2.4.348. 355

Lee, V. E. (2004). Effects of High-School Size on Student Outcomes: Response to Howley and Howley. Education Policy Analysis Archives, 12(53), 1-17. https://doi.org/10.14507/epaa.v12n53.2004

Lindberg, S. M., Hyde, J. S., \& Peterson, J. L. (2010). New Trends in Gender and Mathematics Performance: A meta-Analysis. Psychological Bulletin, 136(6), 1123-1135. https://doi.org/10.1037/ a0021276

Lubienski, C., Crane, C. C., \& Lubienski, S. T. (2008). What Do We Know about School Effectiveness? Academic Gains in Public and Private Schools. Phi Delta Kappan, 89(9), 689-695. https://doi.org/10.1177/003172170808900918

Lubienski, S. T. (2006). Examining Instruction, Achievement, and Equity with NAEP Mathematics Data. Education Policy Analysis Archives, 14(14), 1-33. https://doi.org/10.14507/epaa.v14n14.2006

Meece, J. L., Wigfield, A., \& Eccles, J. S. (2010). Predictors of Math Anxiety and its influence on Young Adolescents' Course Enrollment Intention and Performance in Mathematics. Journal of Educational Psychology, 82(1), 60-70. https://doi.org/10.1037/00220663.82.1.60

Meremikwu, A., \& Enukoha, O. (2010). Instructional aids, school variables and pupil's Mathematics achievement in primary schools in Cross River State, Nigeria. In M. Joubert, \& P. Andrews (Eds.), Proceedings of the British Congress for Mathematics Education, April, 2010.

Mukhopadhuyay, S., \& Greer, B. (2007). How many deaths? Education for statistical empathy, The Montana Mathematics Enthusiast. Monograph, 1, 119-135.

Mutemrri, J., \& Mugweni, R. (2005). The extent to which Mathematics instructional practices in early childhood education in Zimbabwe relates to or makes use of children's experiences. African Journal of Research in Mathematics, Science and Technology Education, 9(1), 4954. https://doi.org/10.1080/10288457.2005.10740576

National Council of Teachers of Mathematics. (1989). Curriculum and evaluation standard for school Mathematics. Reston, V.A.: National Council on Teachers of Mathematics.

National Examination Council. (2015). Basic Education Certificate Examination (BECE).

Nokoe, K. S. (2008). The marriage of Mathematics and Biology: life assessment for sustainable development. Ghana Academy of Arts and Sciences.

Obodo, G. C. (2004). Principle and practice of Mathematics Education in Nigeria. Enugu: Floxtone Press. 
Odili, G. A. (2012). Towards A New Paradigm of Teaching Mathematics in Nigeria University. The Role of Mathematics Educators. Online Journal of Science Teachers Association of Nigerian (STAN), 47(1).

Odogwu, H. N. (2002) Temale students perception and attitude to Mathematics. A bane to their S.M.T Education. ABACUS journal of the Mathematics Association of Nigeria, 27(1), 19-29.

Oduwaiye, J. O. (2009). Impact of Computer-Assisted and programmed instructions on Pre-service Teachers Learning Outcomes in some Environmental Education Concepts in Biology (Ph.D Thesis). Faculty of Education, University of Ibadan, Nigeria.

Ofoegbu, F.I. (2004). Teacher Motivation: A Factor for Classroom Effectiveness and School Improvement in Nigeria. College student journal, $38,81$.

Ogochukwu, N. V. (2010). Enhancing students interest in Mathematics via multimedia presentation. African Journal Mathematics and Computer Science Research, 3(7), 107-113.

Ojo, T. A. (2009). Impact of video CD and Audio cassette Instructions on students Learning Outcomes in some environmental education concept in Biology (Ph.D Thesis), Faculty of Education, University of Ibadan, Nigeria.

Okeke E. A. C. (2001). Women in Science, Technology and Mathematics Education in Nigeria. In O. O. Busari (Ed.), Women in Science, Technology and Mathematics Education. 42nd Annual Conference Proceedings of the Science Teachers Association of Nigeria. Ibadan: A STAN Publication (3-13)

Okoye, E. A. C. (2010). Classroom environment, Computers and students' effective Performance. An effective profile. Journal of Experimental Education, 62, 221-239. https://doi.org/10.1080/ 00220973.1994 .9943842

Oladayo, O. T., \& Oladayo, C. E. (2012). Effects of Direct and Indirect Instructional Strategies on Students Achievements in Mathematics. An international Multidisciplinary Journal, 6(27), 349-361. https://doi.org/10.4314/afrrev.v6i4.24

Olaleye, O. O. (2004). Some Psychological Determinant of Secondary School Female students Achievements in Mathematics in Osun and Oyo State, Nigeria (Unpublished Ph.d Thesis). University of Ibadan.

Olatundun, S. A. (2008). Impact of Outdoor Educational activities on pupils' environmental knowledge and attitude in selected primary schools in Ibadan, Nigeria (Ph.D Thesis). Department of Teacher Education, University of Ibadan.

Olumuyiwa, S. A. (2012). Self Efficacy, Locus of control, Self Assessment of Memory Ability and Study Habits as Predictors of Pre-service Teachers Achievement in Mathematics (Unpublished M.Ed dissertation). University of Ibadan.

Oluokun, O., \& Oyeniran, J. O. (2006). Towards effective teaching and learning of Mathematics in primary schools in Oyo State. Oyo SUBEB training manual for primary school teachers in Oyo State. Oyo. Odumatt. 40-58.

Olusi, F. I., \& Anuolu, E. (2010). Mathematics as a foundation for children Education in Science and Technology. Pakistan Journal of Education and Technology, 1, 65-168. https://doi.org/10.3923/ pjssci.2010.275.278
Onobanjo, I. O. (2010). Peer tutoring - assisted instruction, parent supportiveness and students locus of control as determinants of learning outcomes in S.S.S Mathematics (Unpublished Ph.d Thesis). University of Ibadan.

Orey, D. C., \& Rosa, M. (2006). EthnoMathematics cultural assertions and challenges towards pedagogical action. Journal of Mathematics and Culture, 1(1), 57-78.

Oteyemi, A. F. (2001). Effects of two teaching strategies on students performance in secondary school Mathematics (Unpublished M.Ed Dissertation). Olabisi Onabanjo University, Ago-iwoye, Nigeria

Owolabi, J., \& Etuk-iren, O. A. (2014). Gender, Course of study and Continuous Assessment as determinants of Students Performance in Pre-NCE Mathematics in South Western Nigeria. American Journal of Mathematics and Science, 2(3), 7-18.

Owoyemi, T. E. (2007). Mathematics and Chemistry senior school certificate result, gender and attitude as predictors of achievement in a physical chemistry course. African Journal of Educational Research 11(1 and 2), 27-34.

Oyedeji, O. A. (2000). Effective Teaching of Mathematics. In S. Y. Erinosho, A. Adesanya, \& A. Ogunyemi (Eds.), Teaching Effectiveness in Nigerian schools (pp. 147-167), Ibadan Sam Bookman Publishers.

Oyeniran, J. O. (2003). Teaching methods. An introduction to principle and methods of teaching. Lagos IBIS Publisher.

Philias, O. Y., \& Wanjobi, W. C. (2011). Performance Determinants of Kenya Certificate of Secondary Education (KCSE) in Mathematics of Secondary Schools in Nyamaiya Division, Kenya. Asian Social Science, 7(2), 107-112. https://doi.org/10.5539/ass.v7n2p107

Polya, G. (2009). On teaching Problem-solving. In E. G. Begle (Ed.), Role of Axiomatic and Problem-solving in Mathematics. Washington, D.C: The Conference Board of Mathematical Sciences.

Popoola, A. A. (2002). Effects of Heuristic problem-solving and Programmed Instructional Strategies on Senior Secondary School Students Learning outcomes in Mathematics in Ekiti State, Nigeria (Unpublished Ph.D Thesis), University of Ibadan.

Raimi, S. M., \& Adeoye, F. A. (2002). Gender differences among college students as determinants of performance in integrated sciences. African Journal of Educational Research, 8(1 and 2), 41-49.

Raudenbush, S. W. (2004). Schooling, Statistics, and Poverty: Can We Measure School Improvement?: Educational Testing Service, Princeton N. J. Policy Information Center.

Regina, Y. M. (2010). The effect of school characteristics on student academic performance (Ph.D Thesis), Virginia Polytechnic Institute and State University.

Reid, N. (2003). Gender and physics. International Journal of Science Education, 25(4), 509-536. https://doi.org/10.1080/0950069022000 017270

Rouse, C. E., \& Barrows, L. (2008). Do Education Vouchers Improve Student Learning and Public School Achievement? National Center for the Study of Privatization in Education.

Sanni, S. O., \& Ochepa, I. A. (2002). Effect of practical discussion outside the classroom on Students Performance in Mathematics. Abacus J. MATH. Assoc. Niger, 27(1), 45-52. 
Sara, A. (2012). The impact of using multimedia on students' academic achievement in the College of Education at King Saud University. Journal of King Saud University - Languages and Translation, 24(2), 75 82. https://doi.org/10.1016/j.jksult.2012.05.002

Schoenfeld, A. (1987). Cognitive Science and Mathematics Education. New Jersey: Laurence Erlbaum Associates, Inc.

Schoenfeld, A. H. (2008). Mathematical problem solving. Academic Press.

Singh, S. P., \& Imam, A. (2013). Effect of Personal and Institutional Variables on Mathematics Achievement of Secondary School Students. IOSR Journal of Humanities and Social Science, 10(3), 22-33. https://doi.org/10.9790/0837-01032233

Spelke, E. S. (2005). Sex difference in intrinsicaptitude for Mathematics and science? A critical review. American psychologist 60(9), 950-958. https://doi.org/10.1037/0003-066X.60.9.950

Spelke, E. S., \& Grace, A. D. (2007). Sex, math and science. In S. I. Ceci, \& W. M. William (Eds.), Why aren't more women in science? Top researchers debate the evidence (pp. 57-68). American Psychological Association (APA). https://doi.org/10.1037/11546-005

Stanic, G., \& Kilpatrick, J. (1988). Historical Perspectives on Problem Solving in teaching and assessing of mathematical problem solving (pp. 1-22). Reston, VA: National Council of Teachers of Mathematics

The National Strategies (2007). The framework for secondary Mathematics: Introduction.

Tolhurst, D. (1995). Hypertext, hypermedia, multimedia defined? Education. Technology, 35, 2126.
Toumasis, C. (2006). Expanding in-service Mathematics teachers' horizons in creative work using technology. International Journal of Mathematics Education in Science and Technology, 77(8), 901-912. https://doi.org/10.1080/00207390500503145

Ubuz, B. (1994). Problem Solving Method with handout material: max word problems. International Journal of Mathematics in Science and Technology, 25(3), 367-376. https://doi.org/10.1080/00207399402 50308

Uloko, E. S., \& Imoko, B. I. (2007). Effect of ethno-Mathematics teaching approach and gender on students' achievements in Locus. J. Nad. Assoc. Sci. Humanit. Educ. Res., 5(1), 31-36.

UNESCO. (2004). ICT pedagogy. UNESCO office.

Uzo, A. N. (2002). Mathematics and Students / The secreet of solid background in Mathematics. A hand book for parents, teachers and students. Garki, Abuja: Cradle Crest Publishing.

Velleman, P. F., \& Moore, D. S. (1996). Multimedia for teaching statistics: promises and pitfalls. American Statistician, 50, 217-226. https://doi.org/10.1080/00031305.1996.10474383

WAEC Chief Examiner Report. (2012). The West African Examination Council. Senior Secondary School Certificate Examination Report.

West African Examination Council. (2014). Chief Examiners Report. Lagos WAEC Statistics Division.

Yara, P. O. (2008). School environment and student factors as predictors of achievement in Secondary school Mathematics in South Western Nigeria (Unpublished Ph.D Thesis). University of Ibadan, Ibadan. 